\title{
Combination treatment of an IDH1 inhibitor with chemotherapy in IDH1 mutant acute myeloid leukemia
}

\author{
Charu Gupta $^{1} \cdot$ Stefan Kaulfuss ${ }^{2} \cdot$ Kerstin Görlich $^{1} \cdot$ Basem Othman $^{1} \cdot$ Anuhar Chaturvedi $^{1} \cdot$ Michael Heuser $^{1}$
}

Received: 10 March 2020 / Accepted: 12 March 2020/Published online: 15 April 2020

(C) The Author(s) 2020

\begin{abstract}
Dear Editor,
The first clinical IDH1 inhibitor ivosidenib as a single agent in IDH1-mutated relapsed or refractory acute myeloid leukemia (AML) showed an overall response rate of $41.6 \%$ and a complete remission rate of $21.6 \%$ with a median duration of response of 8.2 months [1]. While these results are promising in this difficult to treat patient setting, they also suggest that mIDH1 inhibitors should be combined with other agents to improve efficacy. IDH1 mutations do not show a clear prognostic effect in AML patients who are treated with standard induction and consolidation therapy [2-5]. It is unclear how an IDH1 inhibitor acts in combination with standard chemotherapy and how the treatment sequence may affect treatment efficacy.

We evaluated the mIDH1 inhibitor BAY1436032 in sequential or simultaneous combination with cytarabine plus doxorubicin in a previously reported IDH1 mutant PDX mouse model [6] (Fig. 1a). All treatment groups that were treated with BAY1436032 received the drug for 87 days (Fig. 1a). While the engraftment of human leukemic cells increased in the vehicle-treated mice at week 8 and in chemotherapy-treated mice at week 12 after the start of treatment, the percentage of leukemic cells decreased in BAY1436032-treated mice as well as in the groups receiving
\end{abstract}

Anuhar Chaturvedi and Michael Heuser contributed equally to this work.

Electronic supplementary material The online version of this article (https://doi.org/10.1007/s00277-020-04001-w) contains supplementary material, which is available to authorized users.

Anuhar Chaturvedi

chaturvedi.anuhar@mh-hannover.de

$\triangle$ Michael Heuser

heuser.michael@mh-hannover.de

1 Department of Hematology, Hemostasis, Oncology and Stem Cell Transplantation, Hannover Medical School, Hannover, Germany

2 Bayer AG, Berlin, Germany the sequential and simultaneous combination treatments (Fig. 1b). However, after the stop of treatment at week 12, the percentage of leukemic cells increased after week 16 in the group receiving BAY1436032 and after week 24 in the group treated with a sequential combination of BAY1436032 and chemotherapy (Fig. 1b). Similar to the combination with azacitidine [7], the percentage of leukemic cells in mice treated with the simultaneous combination of BAY1436032 and chemotherapy showed a delayed increase of blasts and slower leukemia kinetics (Fig. 1b). Importantly, 4 of 8 mice from this cohort had less than $10 \%$ human leukemic cells in the peripheral blood at the end of the study at 48 weeks (Fig. 1c). WBC counts constantly increased and hemoglobin as well as platelet counts decreased in all treatment groups but stayed normal in the group of mice treated simultaneously with BAY1436032 and chemotherapy (Fig. 2a, b, and c). While chemotherapy-treated mice survived longer with a median survival of 206 days compared with vehicle-treated mice with a median survival of 173 days, BAY1436032-treated mice had significantly longer latency with a median survival of 325 days. However, no significant difference in survival was observed between mice treated with BAY1436032 alone and mice treated sequentially with the combination of BAY1436032 and chemotherapy (median survival of 340 days). Importantly, 5/8 mice treated simultaneously with BAY 1436032 and chemotherapy survived until the end of the study at 400 days and the median survival was not reached (Fig. 2d). In summary, only the simultaneous combination of BAY1436032 and chemotherapy showed additive effects in IDH1-mutated human leukemia in vivo.

The findings from our preclinical study show that simultaneously combining an IDH1mutant inhibitor with cytarabine plus doxorubicin substantially inhibits leukemia in vivo. These findings are in accordance with our previous study in which we showed a synergistic effect of simultaneous administration of an IDH1 inhibitor with the hypomethylating agent azacitidine compared with sequential administration [7]. A phase 1 study of a mutant IDH1 inhibitor plus chemotherapy 
a

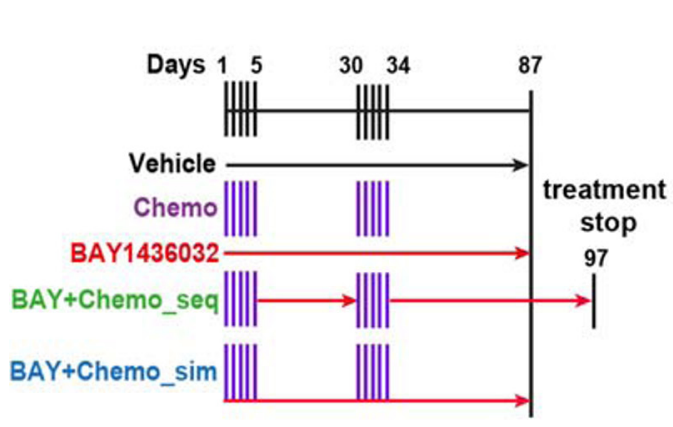

b

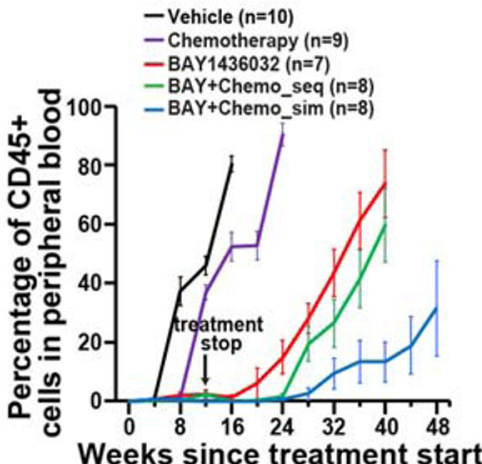

C

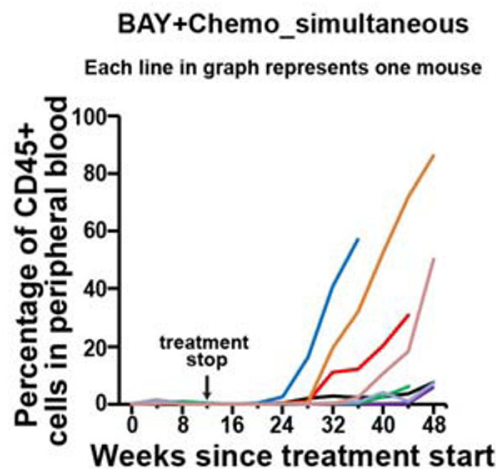

Fig. 1 Mutant IDH1 inhibitor BAY1436032 combined with chemotherapy delays engraftment of leukemic cells in a patient-derived IDH1 mutant AML xenograft model in vivo. a Schematic representation of the treatment regimens; sim, simultaneous treatment with BAY1436032 and chemotherapy; seq, sequential treatment with BAY1436032 and chemotherapy. b Percentage of hCD45+ leukemic cells in peripheral blood of IDH1mutant (R132C) PDX mice at different time points after treatment start with vehicle, chemotherapy (cytarabine
$50 \mathrm{mg} / \mathrm{kg}$ plus doxorubicin $1 \mathrm{mg} / \mathrm{kg}$, days $1-5$ and days $30-34$ ), BAY1436032 (150 mg/kg, p.o., continuously), or the sequential or simultaneous combination of BAY1436032 and chemotherapy according to the treatment regimen shown in Fig. 1a (mean \pm SEM). c Percentage of $\mathrm{hCD} 45+$ leukemic cells in peripheral blood of individual mice transplanted with human IDH1 mutant AML cells and simultaneously treated with BAY1436032 and chemotherapy
Fig. 2 Mutant IDH1 inhibitor BAY1436032 combined with chemotherapy improves survival when simultaneously applied to an AML PDX model. a White blood cell counts after different time points after treatment start with vehicle, chemotherapy (cytarabine $50 \mathrm{mg} / \mathrm{kg}$ plus doxorubicin $1 \mathrm{mg} / \mathrm{kg}$, days $1-5$ and days 30-34), BAY1436032 (150 mg/kg, p.o., q.d., continuously), or the sequential or simultaneous combination of BAY1436032 and chemotherapy according to the treatment regimen shown in Fig. 1a (mean \pm SEM). b Hemoglobin after different time points after the start of treatment (mean \pm SEM). c Platelet count in the peripheral blood of IDH1 mutant PDX mice at different time points after the start of treatment (mean \pm SEM). d Kaplan-Meier survival curves of IDH1mutant PDX mice treated with vehicle, chemotherapy, BAY1436032, or the sequential or simultaneous combination of BAY1436032 and chemotherapy according to the treatment regimen shown in Fig. 1a

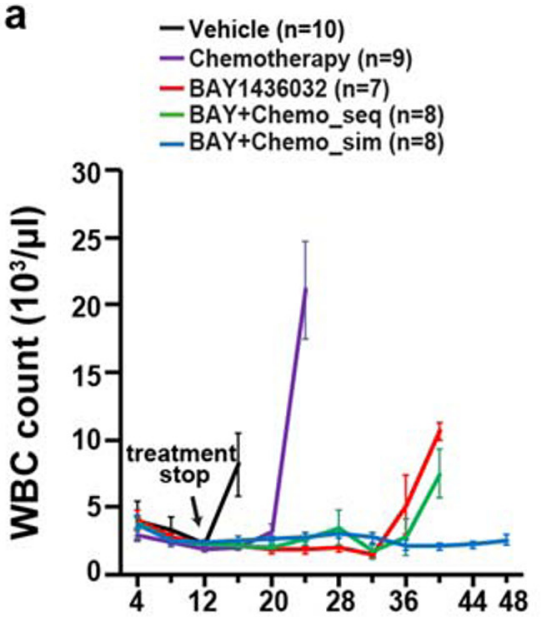

\section{Weeks since treatment start}

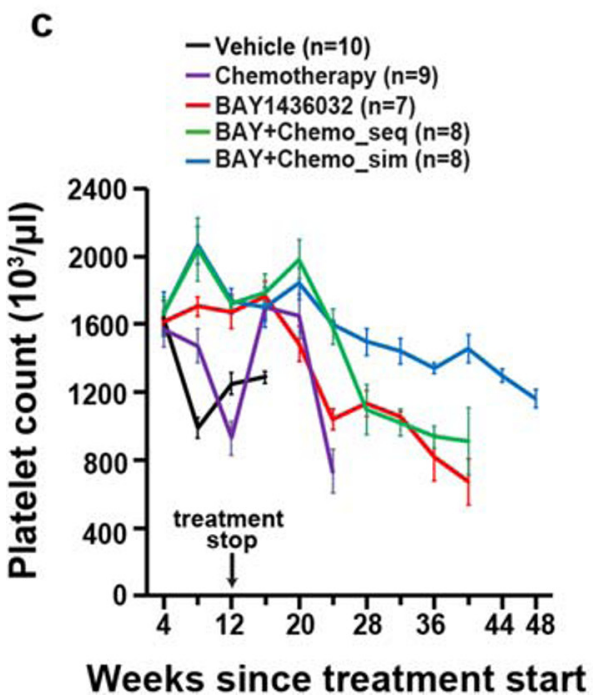

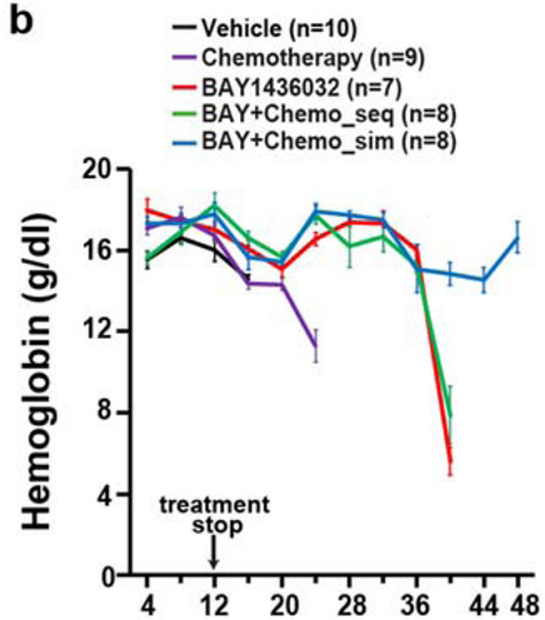

Weeks since treatment start

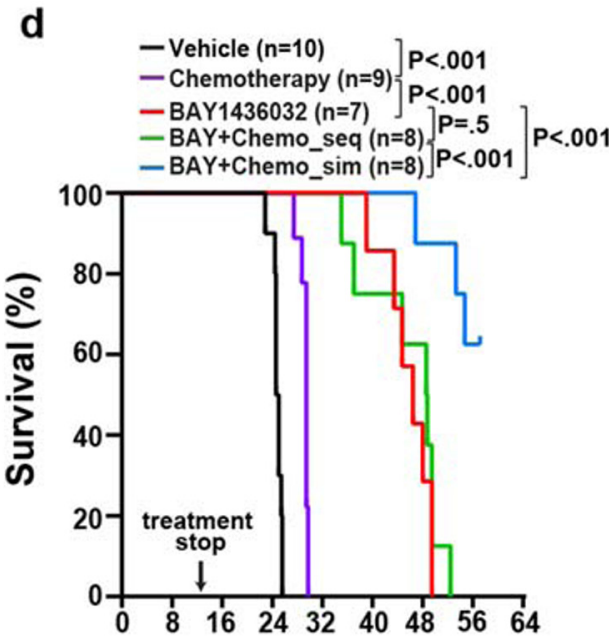

Weeks since treatment start 
in newly diagnosed IDH1mut AML and MDS patients has been initiated (NCT03839771). Initial data have shown a response rate (CR, CRi, or CRp) of $93 \%$ in patients with de novo AML and $63 \%$ in patients with secondary AML [8]. Our data strongly argues for the concurrent application of mIDH1 inhibitors with chemotherapy, and thus informs the design of future studies and predicts improved outcome of this regimen in IDH1-mutated AML patients.

Funding information Open Access funding provided by Projekt DEAL. This work was supported by funding from Bayer AG, grant 70112697 from Deutsche Krebshilfe, an ERC grant under the European Union's Horizon 2020 research and innovation programme (No. 638035), and DFG grants HE 5240/5-2, HE 5240/6-1, and HE5240/6-2.

\section{Compliance with ethical standards}

All applicable national and institutional guidelines for the care and use of animals were followed. Experimental procedures were approved by governmental authorities of Lower Saxony, Germany, and supervised by local animal welfare officials.

Conflict of interest Chaturvedi and M. Heuser received research support for their University from Bayer AG. S. Kaulfuss is an employee of Bayer AG. All other authors have no conflict of interest.

Abbreviations $I D H 1$, isocitrate dehydrogenase 1; $m I D H 1$, mutant isocitrate dehydrogenase $1 ; C R$, complete remission; $C R i$, CR with incomplete hematologic recovery; $C R p$, CR with incomplete platelet counts; $s A M L$, secondary acute myeloid leukemia

Open Access This article is licensed under a Creative Commons Attribution 4.0 International License, which permits use, sharing, adaptation, distribution and reproduction in any medium or format, as long as you give appropriate credit to the original author(s) and the source, provide a link to the Creative Commons licence, and indicate if changes were made. The images or other third party material in this article are included in the article's Creative Commons licence, unless indicated otherwise in a credit line to the material. If material is not included in the article's Creative Commons licence and your intended use is not permitted by statutory regulation or exceeds the permitted use, you will need to obtain permission directly from the copyright holder. To view a copy of this licence, visit http://creativecommons.org/licenses/by/4.0/.

\section{References}

1. DiNardo CD, Stein EM, de Botton S, Roboz GJ, Altman JK, Mims AS, Swords R, Collins RH, Mannis GN, Pollyea DA, Donnellan W,
Fathi AT, Pigneux A, Erba HP, Prince GT, Stein AS, Uy GL, Foran JM, Traer E, Stuart RK, Arellano ML, Slack JL, Sekeres MA, Willekens C, Choe S, Wang H, Zhang V, Yen KE, Kapsalis SM, Yang H, Dai D, Fan B, Goldwasser M, Liu H, Agresta S, Wu B, Attar EC, Tallman MS, Stone RM, Kantarjian HM (2018) Durable remissions with ivosidenib in IDH1-mutated relapsed or refractory AML. N Engl J Med 378:2386-2398

2. Wagner K, Damm F, Gohring G et al (2010) Impact of IDH1 R132 mutations and an IDH1 single nucleotide polymorphism in cytogenetically normal acute myeloid leukemia: SNP rs11554137 is an adverse prognostic factor. J Clin Oncol 28:2356-2364

3. Paschka P, Schlenk RF, Gaidzik VI, Habdank M, Krönke J, Bullinger L, Späth D, Kayser S, Zucknick M, Götze K, Horst HA, Germing U, Döhner H, Döhner K (2010) IDH1 and IDH2 mutations are frequent genetic alterations in acute myeloid leukemia and confer adverse prognosis in cytogenetically normal acute myeloid leukemia with NPM1 mutation without FLT3 internal tandem duplication. J Clin Oncol 28:3636-3643

4. Marcucci G, Maharry K, Wu YZ, Radmacher MD, Mrózek K, Margeson D, Holland KB, Whitman SP, Becker H, Schwind S, Metzeler KH, Powell BL, Carter TH, Kolitz JE, Wetzler M, Carroll AJ, Baer MR, Caligiuri MA, Larson RA, Bloomfield CD (2010) IDH1 and IDH2 gene mutations identify novel molecular subsets within de novo cytogenetically normal acute myeloid leukemia: a cancer and leukemia group B study. J Clin Oncol 28:2348-2355

5. Murphy T, Yee KWL (2017) Cytarabine and daunorubicin for the treatment of acute myeloid leukemia. Expert Opin Pharmacother 18: $1765-1780$

6. Chaturvedi A, Goparaju R, Gupta C, Weder J, Klünemann T, Araujo Cruz MM, Kloos A, Goerlich K, Schottmann R, Othman B, Struys EA, Bähre H, Grote-Koska D, Brand K, Ganser A, Preller M, Heuser M. (2020) In vivo efficacy of mutant IDH1 inhibitor HMS-101 and structural resolution of distinct binding site. Leukemia 34(2):416426. https://doi.org/10.1038/s41375-019-0582-x

7. Chaturvedi A, Herbst L, Pusch S, Klett L, Goparaju R, Stichel D, Kaulfuss S, Panknin O, Zimmermann K, Toschi L, Neuhaus R, Haegebarth A, Rehwinkel H, Hess-Stumpp H, Bauser M, Bochtler T, Struys EA, Sharma A, Bakkali A, Geffers R, Araujo-Cruz MM, Thol F, Gabdoulline R, Ganser A, Ho AD, von Deimling A, Rippe K, Heuser M, Krämer A (2017) Pan-mutant-IDH1 inhibitor BAY 1436032 is highly effective against human IDH1 mutant acute myeloid leukemia in vivo. Leukemia 31(10):2020-2028. https://doi. org/10.1038/leu.2017.46

8. Stein EM, DiNardo CD, Fathi AT et al (2018) Ivosidenib or enasidenib combined with induction and consolidation chemotherapy in patients with newly diagnosed AML with an IDH1 or IDH2 mutation is safe, effective, and leads to MRD-negative complete remissions. Blood 132:560-560

Publisher's note Springer Nature remains neutral with regard to jurisdictional claims in published maps and institutional affiliations. 